\title{
STUDI KASUS PERAN PENYULUH AGAMA ISLAM DALAM REHABILITASI SOSIAL PADA DEWASA TERLANTAR DI UNIT REHABILITASI SOSIAL BINA KARYA MADIUN
}

\author{
Farah Nadiyah Hilmy \\ Fakultas Ushuluddin, Adab, dan Dakwah IAIN Ponorogo \\ hilmynadia30@gmail.com \\ Muhamad Nurdin \\ Fakultas Ushuluddin, Adab, dan Dakwah IAIN Ponorogo \\ muhamadnurdin@iainponorogo.ac.id
}

\begin{abstract}
This study aims to find the efforts of Islamic counseling supervisors in solving the problems of neglected adults at the Social Rehabilitation Unit of Bina Karya Madiun in Ponorogo. This research uses a qualitative descriptive case study research approach. Data collection techniques used are through observation, interviews, and documentation. For technical data analysis using data reduction, data presentation, and drawing conclusions. The results of the study briefly show that the efforts made by Islamic counseling supervisors in solving neglected adult problems according to the field are planning, implementation and evaluation. Islamic counseling guidance methods in meeting the needs of neglected adults according to the field are lectures, dialogues and questions and answers, consultations, talaqqi.
\end{abstract}

Keywords: role of Islamic religious instructor, neglected adults, guidance method metode

\begin{abstract}
Abstrak
Penelitian ini bertujuan untuk menemukan upaya pembimbing penyuluhan Islam dalam penyelesaian masalah dewasa terlantar di Unit Rehabilitasi Sosial Bina Karya Madiun di Ponorogo. Penelitian ini menggunakan pendekatan penelitian studi kasus
\end{abstract}


deskriptif kualitatif. Teknik pengumpulan data yang digunakan yaitu melalui observasi, wawancara, dan dokumentasi. Untuk teknis analisis data dengan menggunakan reduksi data, penyajian data, dan penarikan kesimpulan. Hasil penelitian secara ringkas menunjukkan bahwa upaya yang dilakukan pembimbing penyuluhan islam dalam penyelesaian masalah dewasa terlantar menurut dilapangan yaitu perencanaa, pelaksanaan dan evaluasi. metode bimbingan penyuluhan Islam dalam memenuhi kebutuhan dewasa terlantar menurut dilapangan yaitu ceramah, dialog dan tanya jawab, konsultasi, talaqqi.

\section{Kata Kunci: peran penyuluh agama Islam, dewasa terlantar, metode bimbingan}

\section{PENDAHULUAN}

Pada masa dewasa ini banyak sekali harapan yang ditujukan pada mereka yang memang berada pada masa ini. Banyak sekali tugas-tugas yang harus dikembangkan dan tingkat penguasaan ini akan sangat memengaruhi tingkat keberhasilan mereka ketika sudah berusia beranjak tua. Maka tidak jarang ditemukannya beberapa permasalahan yang dihadapi oleh orang-orang dewasa. Seseorang yang sudah dewasa apabila tidak dapat berhasil dalam tugas-tugas perkembangannya akan mengalami kendala dalam menjalai kehidupanya. Berbagai peran baru tersebut merupakan masalah berat yang harus dihadapi oleh usia dewasa pada umumnya. Akibatnya ketika orang dewasa tidak mampu menjalankan peran ataupun tugas dalam memenuhi kebutuhannya mereka tidak sedikit memilih hidup menelantar ataupun menggelandang. Pengertian orang terlantar adalah seseorang yang karena tertentu, miskin atau tidak mampu, yang tidak dapat terpenuhi kebutuhan dasarnya dengan wajar baik secara jasmani, rohani, maupun sosialnya. Jadi dengan demikian orang terlantar juga termasuk pengemis dan gelandangan. Mereka tidak bisa memenuhi kebutuhan hidupnya sendiri. ${ }^{1}$ Untuk itu perlu adanya upaya yang strategis dalam manangani permasalahan tersebut, baik dari pihak

\footnotetext{
${ }^{1}$ Joko Arif, Peran Pekerja Sosial dalam Merehabilitasi Masalah Pengemis, Gelandangan, dan Orang Terlantar (Pgot) di Panti Pelayanan Sosial Pgot Mardi Utomo Semarang. (Surakarta: IAIN Surakarta, 2017), 18.
} 
masyarakat atau sosialnya, keluarga, pemerintah maupun lembaga-lembaga non pemerintah yang bergerak di bidang penanganan masalah sosial. Maka dari itu peran pembimbing penyuluhan islam sangat dibutuhkan disini, mengingat tugas penyuluh adalah sebagai agen perubahan masyarakat yang mampu mengarahkan, mengembangkan kegiatan bimbingan melalui bahasa agama. ${ }^{2}$ Bentuk bimbingan sosial ini diantaranya mencakup bimbingan fisik dan kesehatan, bimbingan mental dan spiritual hidup bermasyarakat yang termasuk bagian peran penting di balai rehabilitasi sosial dengan tujuan membantu individu menjadi insan yang berakhlakul kharimah. ${ }^{3}$ Disisi lain balai rehabilitasi sosial juga bekerja sama dengan penyuluh dalam rehabilitasi sosial keagamaan.

\section{Penyuluh Agama Islam: Peran dan Fungsi}

Peran (role) termasuk aspek dinamis dari kedudukan (status) artinya, seseorang telah melaksanakan hak-hak dan kewajibannya sesuai dengan kedudukannya, maka orang itu telah melaksanakan suatu peran. Peran dapat diartikan sebagai perilaku individu yang penting bagi struktur sosial masyarakat. ${ }^{4}$ Jadi kata peran yang dimaksud dalam penelitian ini yaitu perilaku seseorang dalam status kedudukannya di masyarakat. Sehingga dapat disimpulkan bahwa peran adalah aspek dinamis berupa perilaku atau tindakan yang dilakukan oleh orang atau badan lembaga yang menduduki suatu posisi dalam situasi sosial. Dalam KBBI pengertian penyuluh menurut bahasa berasal dari kata "suluh" yang berarti benda yang dipakai untuk menerangi. Dalam bahasa sehari hari istilah penyuluh sering digunakan sebagai pemberian penerangan, yang diambil dari kata suluh yang sama

\footnotetext{
${ }^{2}$ Ramlah, Meretas Dakwah di Kota Palopo, (Yogyakarta: CV Budi Utama, 2019), 190.

3 Zahro Aminatuz, Peran Bimbingan dan Penyuluhan Islam dalam Rehabilitasi Sosial Keagamaan Pada Lanjut Usia Terlantar di Unit Rehabilitasi Sosial "Mandiri” Semarang II, (Semarang: UIN Walisongo, 2014), 4-5.

${ }^{4}$ J. Dwi Narwoko, Dan Bagong Suyanto, Sosiologi Tes Pengantar dan Terapan, (Jakarta:Kencana, 2007), Cet Ke-3, 158-159
} 
artinya dengan "obor". ${ }^{5}$ Jadi kata peran yang dimaksud dalam penelitian ini yaitu perilaku seseorang dalam status kedudukannya di masyarakat. Sehingga dapat disimpulkan bahwa peran adalah aspek dinamis berupa perilaku atau tindakan yang dilakukan oleh orang atau badan lembaga yang menduduki suatu posisi dalam situasi sosial. Peran penyuluh bukan hanya melakukan penyuluhan agama dalam artian berupa pengajian saja, akan tetapi seluruh kegiatan pemahaman baik berupa bimbingan ataupun penerangan di berbagai progam pembangunan. Dilihat dari posisi penyuluh saat ini bahwasannya sangat strategis bagi penyuluh dalam melakukan tugas atau misi keagamaan maupun pembangunan dengan rasa tanggung jawab yang dapat membawa masyarakat kepada kehidupan yang aman dan sejahtera.

Fungsi informatif dan edukatif yaitu sebagai penyuluh agama islam selain dirinya juga sebagai dai yang berkewajiban mendakwahkan Islam, penyuluh juga menyampaikan pemahaman atau penerangan agama serta mendidik masyarakat sebaik-baiknya sesuai dengan tuntutan Al-qur'an dan Sunnah Nabi. Fungsi konsultatif yaitu penyuluh agama Islam juga berfungsi menjadikan dirinya untuk turut memikirkan dan memecahkan persoalan-persoalan yang dihadapi masyrakat, baik persoalan-persoalan pribadi, keluarga atau persoalan masyarakat secra umum. Fungsi advokatif yaitu pembelaan ataupun dukungan positif yang bertujuan mengupayakan solusi bagi suatu masalah melalui kebijaan publik. Sedangkan selain beberapa fungsi tersebut tugas pokok penyuluh agama yaitu melakukan dan mengembangkan kegiatan bimbingan atau penyuluhan serta pembangunan melalui bahasa agama lalu juga memberikan konsultasi arahan dalam meningkatkan ketaqwaan dan kerukunan umat beragama. ${ }^{6}$

\footnotetext{
${ }^{5}$ Kamus Besar Bahasa Indonesia, Pusat Bahasa Departemen Pendidikan Nasional Edisi Ketiga, (Jakarta: Balai Pustaka, 2005), 1101.

${ }^{6}$ Ramlah, Meretas Dakwah di Kota Palopo, (Yogyakarta: cv budi utama, 2019), 190.
} 


\section{Metode Bimbingan Penyuluhan Agama Islam}

Dalam penyuluhan maka diperlukan beberapa teknik penyuluhan diantaraya perencanaan, pelaksanaan, evaluasi. Dalam melakukan suatu kegiatan bimbingan penyuluhan islam maka perlu adanya penggunaan metode di dalamnya. Metode sendiri mempunyai makna cara teratur atau bersistem yang digunakan untuk melaksanakan suatu pekerjaan guna mencapai tujuan yang ditentukan. ${ }^{7}$ Ceramah dari aspek segi bahasa dapat diartikan sebagai penuturan atau penerangan secara lisan oleh guru pendidikan agama islam terhadap peserta didiknya di dalam kelas. Alat yang digunakan yaitu "berbicara". Sementara pengisi ceramah menyampaikan materinya kepada para peserta atau audien mendengarkan dengan teliti mencatat pokok pokok penting yang telah dikemukakan. ${ }^{8}$ Metode dialog yaitu percakapan atau silih berganti anatara dua orang atau lebih yang didalamnya terdapat tujuan dan topik tertentu serta mempunyai manfaat bagi pelaku dan pendengarnya. Dialog juga merupakan cara yang efektif dan menyenangkan dalam menyampaikan suatu pesan sebagaimana yang telah dicontohkan oleh Allah SWT dan Rasulullah SAW. ${ }^{9}$ Metode tanya jawab adalah cara penyajian pelajaran dalam bentuk pertanyaan, yang dikemukakan oleh guru yang harus dijawab oleh siswa. Konsultasi adalah pertukaran untuk mendapatkan kesimpulan nasihat, saran, dan sebagainya yang sebaik baiknya. ${ }^{10}$ Metode Talaqqi dari segi bahasa diambil dari pada perkataan yaitu belajar secara berhadapan dengan guru. Sering pula disebut musyafahah, yang bermakna dari mulut ke mulut (pelajar belajar Al-Qur'an dengan memperhatikan gerak bibir guru untuk mendapatkan pengucapan makhraj yang benar). ${ }^{11}$

\footnotetext{
${ }^{7}$ Https://www.google.com/amp/s/kbbi.web.id/metode.htnl

${ }^{8}$ Syahraini Tambak, Metode Ceramah: Konsep Dan Aplikasi Dalam Pembelajaran Pendidikan Agama Islam, Jurnal Tarbiyah, Vol. 21, No.2, Juli-Desember 2014

${ }^{9}$ Djamarah Syaiful Bahri, Pola Asuh Orang Tua Dan Komunikasi Dalam Keluarga, (Jakarta: Rineka Cipta, 2014), hal. 198-199.

10 https://www.google.com/amp/s/kbbi.web.id/konsultasi.html

${ }^{11}$ Abdul Qawi, Peningkatan Prestasi Belajar Hafalan Al-Qur'an Melalui Metode Talaqqi Di Mtsn Gampong Teungoh Aceh Utara, Jurnal Ilmiah Islam Futura Vol. 16. No. 2, Februari 2017
} 


\section{Rehabilitasi Sosial Keagamaan dan Dewasa Terlantar}

Rehabilitasi merupakan gabungan antara kata " $r$ " yang berarti kembali dan "habilitasi" adalah kemampuan. Sehingga rehabilitasi sendiri dapat diartikan secara umum sebuah proses untuk membantu sesuatu agar dapat kembali seperti sedia kala, atau paling tidak terdapat pengganti yang sama seperti sebelumnya. ${ }^{12}$ Keagamaan berasal dari kata agama yang kemudian mendapat awalan "ke" dan akhiran "a" sehingga membentuk kata baru yaitu "keagamaan". Sehingga keagamaan di sini mempunyai arti segenap kepercayaan kepada Tuhan serta dengan ajaran kebaikan dan kewajiban yang berkaitan dengan kepercayaan itu. ${ }^{13}$ Pengertian orang terlantar adalah seseorang yang karena tertentu miskin/tidak mampu, yang tidak dapat terpenuhi kebutuhan dasarnya dengan wajar baik secara jasmani, rohani, maupun sosialnya. Sehingga dengan demikian orang terlantar juga termasuk pengemis dan gelandangan. Mereka tidak bisa memenuhi kebutuhan hidupnya sendiri. ${ }^{14}$

Berdasarkan pemaparan diatas maka tujuan dari penelitian ini adalah memahami peranan penyuluh agama Islam dalam memberikan bimbingan dan rehabislitasi sosial keagamaan kepada dewasa terlantar di Unit Rehabilitasi Sosial Bina Karya Madiun.

\section{METODE PENELITIAN} agustus 2020

${ }^{12}$ Sri Astutik, Rehabilitsi Sosial, http://digilib.uinsby.ac.id/id/eprint/20029, terakhir diakses 14

${ }^{13}$ Departemen Pendidikan dan Kebudayaan, Kamus Besar Bahasa Indonesia, edisi II (Jakarta: Balai Pustaka, 1986), 10

${ }^{14}$ Joko Arif, Peran Pekerja Sosial dalam Merehabilitasi Masalah Pengemis, Gelandangan, dan Orang Terlantar (Pgot) di Panti Pelayanan Sosial Pgot Mardi Utomo Semarang. ( Surakarta: IAIN Surakarta, 2017), 4. 
Jenis penelitian ini adalah penelitian kualitatif. Penelitian kualitatif adalah suatu penelitian ilmiah yang bertujuan untuk memahami suatu fenomena dalam konteks sosial secara alamiah dengan mengedepankan proses interaksi komunikasi yang mendalam antara peneliti dengan fenomena yang diteliti. Penelitian ini adalah penelitian kualitatif yaitu penelitian yang menghasilkan penelitian yang valid dan sesuai realita yang ada. ${ }^{15}$ Penelitian ini menggunakan metode penelitian studi kasus (case study). Pendekatan penelitian yang digunakan dalam penelitian ini adalah pendekatan deskriptif kualitatif, karena peneliti menganalisis dan menggambarkan peneliti secara objektif dan mendetail untuk mendapatkan hasil yang akurat terkait pada penelitian ini, yang berfokus untuk mengetahui peran pembimbing penyuluhan Islam dalam rehabilitasi sosial keagamaan pada dewasa terlantar yang berada di Unit Rehabilitasi Sosial Bina Karya Madiun di Ponorogo.

\section{HASIL PENELITIAN}

Peran Penyuluh Agama Islam dalam penyelesaian masalah dewasa terlantar di Unit Rehabilitasi Sosial Bina Karya Madiun Ponorogo. Setelah peneliti mengumpulkan data-data yang diperoleh dari penelitian melalui metode wawancara dan observasi, maka peneliti telah mendeskripsikan data sesuai dengan hasil penelitian. Dalam sebuah kegiatan mencapai tujuan perlu membutuhkan beberapa pengelolaan yakni perencanaan, pelaksanaan dan evaluasi. ${ }^{16}$ Berkaitan dalam mencapai tujuan yang maksimal peran menjadi suatu hal penting sebagai salah satu fungsi yang erat kaitannya langsung dengan manusia dalam mewujudkan tujuan hidup bersama.

Sebagai agen perubahan dalam masyarakat, penyuluh dalam perannya mengarahkan ataupun mengembangkan kegiatan bimbingan melalui bahasa agama. Adapun peran penyuluh yang termuat di teori adalah sebagai pendidik, yaitu

\footnotetext{
${ }^{15}$ Lexy J. Moleong, Metodologi Peneltian Kualitatif, (Bandung: PT. Rosdakarya)1994., 3

${ }^{16}$ Wawancara dengan Ibu Indun Fanani, Senin, 14 September 2020, di Kementerian Agama Ponorogo, Lihat Transkip Wawancara Nomor 02/W/14-09-2020.
} 
melakukan fungsi edukasi yang Islami, penyuluh dituntut harus lebih menguasai ajaran Islam dari rata-rata masyarakat agar mampu melaksanakan perintah allah dan menjauhi larangan-Nya. ${ }^{17}$ Hal tersebut sama dengan apa yang ada di lapangan dengan adanya pemberian keilmuan ataupun edukasi tentang keagamaan berupa kegiatan bimbingan penyuluhan Islam bertemakan mental agama dan baca tulis AlQur'an. Kemudian data yang sesuai dengan penemuan peneliti dilapangan sebagai berikut:

\section{Penggunaan perencanaan}

Perencanaan yang digunakan penyuluh adalah untuk mengajak masyarakat dalam peningkatan ibadah. ${ }^{18}$ Kemudian menurut peneliti yang dilakukan di lapangan penggunaan perencaan ini sudah efektif, mengingat hal itu telah dibuktikan dalam temuan data yang peneliti bahas di bab III mengenai kerjasama sampai dengan jadwal pelaksanaan.

2. Penggunaan pelaksanaan

Pelaksanaan yang dilakukan penyuluh merupakan proses penanaman motivasi kepada masyarakat untuk peningkatan kesadaran dalam pelaksanaan ibadah yang dilakukan secara terjadwal dan berkesinambunga. ${ }^{19}$ Hal itu sesuai dengan apa yang terjadi di lapangan dengan adanya pelaksanaan bimbingan yang diadakan setiap hari rabu dengan tema mental agama dan hari jumat dengan tema baca tulis al-qur'an. Para dewasa terlantar yang sebelumnya bahkan tidak mengetahui tentang agama Islam dan seluk beluknya, sekarang dengan adanya pelaksanaan ini para warga sedikit demi sedikit sudah mulai paham dan mengetahui tentang agama Islam. Hal ini telah peneliti paparkan di bab III dari hasil observasi yang peneliti lakukan.

${ }^{17}$ Sunarso Budi, Peran Kantor Urusan Agama dan Penyuluh dalam Memberikan Bimbingan Perkawinan Pada Masyarakat di Udapi Hilir Prafi Kabupaten Manokwari, (Ponorogo: Myria Publisher, 2019), 25-26.

${ }^{18}$ Maqbul, Moch. Natsir Mahmud, Muliaty Amin, et, Proses Pelaksanaan Strategi Penyuluh Agama Islam Di Kabupaten Baru, Jurnal Diskursus Islam, Vol. 7 No. 3, 2019.

${ }^{19}$ Ibid., 
Kemudian penggunaan pelaksanaan ini menurut peneliti sudah efektif melihat adanya perubahan setelah adanya pelaksanaan tersebut.

3. Penggunaan Evaluasi

Menurut servien dalam teorinya mengatakan bahwa evaluasi adalah proses yang dilakukan untuk membantu staf memperbaiki apapun yang mereka laksanakan atau bangun yang bertujuan untuk menyediakan informasi sebagai dasar memperbaiki program, serta untuk mencatat dan menilai prosedur kegiatan dan peristiwa. ${ }^{20}$ Kemudian evaluasi yang peneliti temukan dilapangan dari hasil observasi yaitu bahwasannya untuk hal yang sudah tercapai oleh penyuluh adalah pertama, para dewasa terlantar yang sebelumnya dalam mengikuti bimbingan penyuluhan islam masih dipaksa oleh petugas pekerja sosial di unit rehabilitasi sosial bina karya Madiun di Ponorogo sudah mulai datang dengan sendirinya atas kesadaran masingmasing.

Kedua, setelah dilakukan bimbingan penyuluhan Islam para dewasa terlantar menjadi lebih mandiri untuk menyelesaikan kebutuhan dan masalahnya masingmasing. Ketiga, setelah dilakukan bimbingan penyuluhan Islam para dewasa terlantar sudah mampu membaca Al-Qur'an, shalat tepat waktu dan pengetahuan akan keagamaan yang meningkat. Kekurangan yang diperoleh peneliti dalam observasi pada evaluasi ini adalah peserta yang mengikuti bimbingan penyuluhan Islam masih belum semuanya ikut dari jumlah populasi para dewasa terlantar di Unit Rehabilitasi Sosial Bina Karya Madiun di Ponorogo.

Metode Bimbingan Penyuluhan Islam dalam Memenuhi Kebutuhan Dewasa Terlantar di Unit Rehabilitasi Sosial Bina Karya Madiun di Ponorogo. Untuk mencapai proses atau cara sistematis perlu adanya metode yang menggambarkan suatu cara totalitas akan tujuan yang dicapai, memenuhi sesuai dengan rencana. Menurut KBBI metode sendiri mempunyai makna cara teratur atau bersistem yang

\footnotetext{
${ }^{20}$ Amirah Diniaty, Evaluasi Bimbingan Konseling, (Riau: Zanafa Publishing 2012), 69
} 
digunakan untuk melaksanakan suatu pekerjaan guna mencapai tujuan yang ditentukan. ${ }^{21}$ Adapun metode yang digunakan penyuluh dalam bimbingan ini diantaranya:

\section{Penggunaan Metode Ceramah dalam Bimbingan Penyuluhan Islam}

Metode ini sangat lazim kita temui di beberapa kegiatan. Selain metode yang terbilang mudah, ceramah juga merupakan metode yang mampu diterima oleh kalangan muda sampai tua. Metode ceramah menurut Armai Arif adalah cara menyampaikan sebuah materi pelajaran dengan cara penuturan lisan kepada peserta didik atau khalayak ramai. Pengertian ini mengarahkan bahwa metode ceramah menekankan pada sebuah pemberian materi pembelajaran dengan cara penuturan lisan. $^{22}$

Hal ini sudah sesuai yang peneliti lakukan dengan apa yang terjadi di lapangan, bahwasannya penggunaan metode ceramah yang penyuluh gunakan dalam bimbingan mental agama dikarenakan metode ini mudah dipahami oleh khalayak umum. feedback dari para warga pun dirasa oleh para penyuluh. Warga yang mengikuti ceramah menjadi lebih antusias mendengarkan serta para warga menjadi lebih mengerti dan memahami dari ceramah yang telah disampaikan. Sehingga penggunaan metode ceramah ini menurut peneliti sudah bisa dikatakan efektif.

2. Penggunaan Metode Dialog dan Tanya Jawab dalam Bimbingan Penyuluhan Islam. Dalam menarik perhatian dan pemahaman audien maka diperlukan sebuah metode yang mendukungnya. Salah satu bentuk metode yang dirasa penyuluh efektif dan cocok ialah metode dialog dan tanya jawab. Menurut Ilham dalam Jurnalnya dialog merupakan metode yang cara penyampaian materinya mendorong sasaran untuk

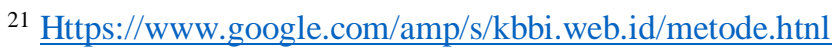

22 Syahraini Tambak, Metode Ceramah: Konsep Dan Aplikasi Dalam Pembelajaran Pendidikan Agama Islam, Jurnal Tarbiyah, Vol. 21, No.2, Juli-Desember 2014. 
menanyakan atau mengatakan sesuatu masalah yang dirasa belum mengerti dan penyampai materi sebagai penjawabnya. ${ }^{23}$

Menurut R. Ibrahim metode tanya jawab adalah metode mengajar yang memungkinkan terjadinya komunikasi langsung yang bersifat dua arah sebab pada saat yang sama terjadi dialog antara guru dan siswa, guru bertanya dan siswa menjawab atau siswa bertanya dan guru menjawab. ${ }^{24} \mathrm{Hal}$ tersebut sama dengan apa yang terjadi di lapangan. Dalam bimbingannya penggunaan metode dialog dan tanya jawab penyuluh aplikasikan di sela-sela ceramah dan diakhir ceramah.

Kemudian menurut peneliti lihat dilapangan ternyata penggunaan metode ini cukup efektif dilihat dari para dewasa terlantar yang bertanya mengenai apa yang sudah disampaikan. Meskipun orang yang bertanya hanya orang-orang itu saja. Namun dengan demikian metode ini secara tidak langsung penyuluh sangat terbantu untuk mengetahui bagaimana respon dari para dewasa terlantar.

3. Penggunaan Metode Konsultasi dalam Bimbingan Penyuluhan Islam Untuk menumbuhkan motivasi rasa keagamaan pada para dewasa terlantar maka perlu adanya arahan atau bimbingan dari penyuluh. Karena peran penyuluh dilapangan bukan sebagai pemberi materi atau motivaor saja akan tetapi juga sekaligus menjadi pembimbing para dewasa terlantar dalam menumbuhkan dan melaksanakan kegiatan beragama. Menurut teori Elfi Mu'awanah dkk, layanan konsultasi merupakan proses dalam suasana kerja sama dan hubungan antar pribadi dengan tujuan memecahkan suatu masalah dalam lingkup professional dari orang yang meminta konsultasi.

Kemudian penggunaan metode ini dilapangan menurut peneliti hanya sebagai metode penunjang saja, karena ternyata warga dewasa terlantar masih jarang sekali yang ingin berkonsultasi. Sehingga penggunaan metode konsultasi ini tidak

${ }^{23}$ Ilham, Peranan Penyluh Agama Islam Dalam Dakwah, Jurnal Alhadharah, Vol. 17 No. 33 Januari - Juni 2018

${ }^{24}$ Fathony, Pengaruh Metode Tanya Jawab Terhadap Hasil Belajar Siswa Di Smk Negeri 1 Peranap Kabupaten Indragiri Hulu, Jurnal Pendidikan Tambusai Volume 3 Nomor 1 Tahun 2019. 
berlangsung setiap penyuluhan berlangsung, akan tetapi hanya ketika ada beberapa para dewasa terlantar yang ingin konsultasi, baik personal maupun kelompok.

4. Penggunaan Metode Talaqqi dalam Bimbingan Penyuluhan Islam

Dalam menjalankan bimbingan baca tulis Al-Qur'an penyuluh menggunakan metode talaqqi. Menurut teori Abdul Qawi dalam jurnalnya, pembelajaran dengan metode talaqqi dapat dilakukan dengan dua cara. Pertama, seorang guru membaca atau menyampaikan ilmunya di depan peserta didiknya sedang para peserta didik menyimaknya, yang mungkin di akhiri dengan pertanyaan-pertanyaan. Kedua, peserta didik membaca di depan guru lalu guru membenarkan jika ada kesalahan dalam bacaan peserta didik. ${ }^{25}$

Kemudian dilihat dari observasi yang peneliti lakukan di lapangan, penggunaan metode talaqqi ini sudah sesuai dengan teori yaitu dibuktikan dengan pemberian bimbingan baca tulis Al-Qur'an dengan memberikan lembar kertas berupa potongan ayat yang kemudian penyuluh membacakan kertas tersebut dengan bacaan yang benar, kemudian diikuti oleh para dewasa terlantar. Dengan adanya metode ini para dewasa terlantar yang notabennya masih belum lancar membaca serta belum fasih, sekarang para dewasa terlantar menjadi lebih lancar membaca meskipun belum sesempurna yang diharapkan. Dengan perkembangan ini maka penggunaan metode ini bisa dikatakan berhasil dan efektif.

\section{PENUTUP}

Upaya Penyuluh Agama Islam dalam penyelesaian masalah dewasa terlantar di Unit Rehabilitasi Sosial Bina Karya Madiun di Ponorogo adalah perencanaan dalam mempersiapkan pelaksanaan penyuluhan diantaranya kerjasama dengan Dinas Sosial Provinsi Jawa Timur yang menaungi Unit Rehabilitasi Sosial Bina Karya Madiun di Ponorogo, menerima SK dari Provinsi Jawa Timur, menerima

${ }^{25}$ Abdul Qawi, Peningkatan Prestasi Belajar Hafalan Al-Qur'an Melalui Metode Talaqqi Di Mtsn Gampong Teungoh Aceh Utara, Jurnal Ilmiah Islam Futura Vol. 16. No. 2, Februari 2017 
jadwal kegiatan penyuluhan, koordinasi rutin dengan pengurus setiap 1 bulan sekali ( teknis, jadwal, materi dan evaluasi). Untuk pelaksanaan penyuluhan diakukan secara terjadwal dan berkesinambungan yaitu pelaksanaan bimbingan penyuluhan Islam dengan tema mental agama dan bimbingan penyuluhan Islam dengan tema baca tulis al-qur'an. Kemudian evaluasi berupa penilaian mengenai hal yang sudah tercapai dalam penyuluhan dan kekurangan yang menjadi hambatan penyuluhan. untuk metode bimbingan penyuluhan Islam dalam memenuhi kebutuhan dewasa terlantar di Unit Rehabilitasi Sosial Bina Karya Madiun di Ponorogo diantaranya ceramah, dialog dan tanya jawab, konsultasi dan talaqqi.

Berdasarkan hasil penelitian ada beberapa saran yang ingin diberikan peneliti, sebagai berikut:

1. Untuk upaya, penyuluh sebaiknya lebih di tingkatkan lagi dalam memberikan bimbingannya khususnya keagamaan kepada para dewasa terlantar di unit rehabilitasi sosial bina karya Madiun di Ponorogo, mengingat hal itu sangat penting bagi kehidupan dunia maupun akhirat.

2. Untuk metode, sebaiknya dalam penggunaanya penyuluh dapat memberikan lebih banyak lagi atau lebih menarik lagi agar para dewasa terlantar yang ikut dalam bimbingan tidak merasa bosan dan jenuh.

\section{DAFTAR RUJUKAN}

Arif, Joko. Peran Pekerja Sosial dalam Merehabilitasi Masalah Pengemis, Gelandangan, dan Orang Terlantar (Pgot) di Panti Pelayanan Sosial Pgot Mardi Utomo Semarang. Surakarta: IAIN Surakarta, 2017.

Astutik, Sri. Rehabilitasi Sosial, http://digilib.uinsby.ac.id/id/eprint/20029, [terakhir diakses 14 agustus 2020]

Bahri, Djamarah Syaiful. Pola Asuh Orang Tua Dan Komunikasi Dalam Keluarga. Jakarta: Rineka Cipta. 2014. hlm. 198-199. 
Rosyada: Islamic Guidance and Counseling

Vol 2. No. 12021

Budi, Sunarso. Peran Kantor Urusan Agama dan Penyuluh dalam Memberikan Bimbingan Perkawinan Pada Masyarakat di Udapi Hilir Prafi Kabupaten Manokwari. Ponorogo: Myria Publisher. 2019. hlm.25-26.

Departemen Pendidikan dan Kebudayaan. Kamus Besar Bahasa Indonesia, edisi II. Jakarta: Balai Pustaka, 1986. hlm.10

Diniaty, Amirah. Evaluasi Bimbingan Konseling. Riau: Zanafa Publishing, 2012.

Fathony. Pengaruh Metode Tanya Jawab Terhadap Hasil Belajar Siswa Di Smk Negeri 1 Peranap Kabupaten Indragiri Hulu, Jurnal Pendidikan Tambusai. 2019 Volume 3. Nomor 1.

https://www.google.com/amp/s/kbbi.web.id/metode.htnl

Ilham, Peranan Penyluh Agama Islam Dalam Dakwah, Jurnal Alhadharah, Vol. 17 No. 33 Januari - Juni 2018

Maqbul, Mahmud, Moch. Natsir. Amin, Muliaty. dkk. Proses Pelaksanaan Strategi Penyuluh Agama Islam Di Kabupaten Baru, Jurnal Diskursus Islam, Vol. 7 No. 3, 2019.

Moleong, Lexy J. Metodologi Peneltian Kualitatif. Bandung: PT. Rosdakarya. 1994., hlm.3

Narwoko, D.J. \& Suyanto, Bagong. Sosiologi Tes Pengantar dan Terapan. Jakarta: Kencana, 2007, Cet Ke-3, hlm.158-159

Puput Syaiful Rohman. Penelitian Kualitatif, Januari 2009, Vol 5.

Pusat Bahasa Departemen Pendidikan Nasional. Kamus Besar Bahasa Indonesia, Edisi Ketiga, Jakarta: Balai Pustaka, 2005, 1101.

Qawi, Abdul Qawi. Peningkatan Prestasi Belajar Hafalan Al-Qur'an Melalui Metode Talaqqi Di MTsn Gampong Teungoh Aceh Utara. Jurnal Ilmiah Islam Futura Vol. 16. No. 2, Februari 2017

Ramlah. Meretas Dakwah di Kota Palopo. Yogyakarta: CV. Budi Utama, 2019.

Tambak, Syahraini. Metode Ceramah: Konsep Dan Aplikasi Dalam Pembelajaran Pendidikan Agama Islam, Jurnal Tarbiyah, Vol. 21, No.2, Juli-Desember 2014. 
Rosyada: Islamic Guidance and Counseling

Vol 2. No. 12021

Wawancara dengan Ibu Indun Fanani, Senin, 14 September 2020, di Kementerian Agama Ponorogo, Lihat Transkip Wawancara Nomor 02/W/14-09-2020.

Zahro, Aminatuz. Peran Bimbingan dan Penyuluhan Islam dalam Rehabilitasi Sosial Keagamaan Pada Lanjut Usia Terlantar di Unit Rehabilitasi Sosial "Mandiri" Semarang II. Semarang: UIN Walisongo, 2014. 